\title{
OIKOUMENE EN PERIPHEREIA IN DIE MARE ERYTHRAEUM-GEBIED IN DIE VROEG-CHRISTELIKE PERIODE
}

\author{
Benjamin Hendrickx (Randse Afrikaanse Universiteit)
}

In sy studie, Europe and the People without History, het die Amerikaanse antropoloog en historikus E.R. Wolf (1982:3-5) die stelling gemaak dat die wêreld se beskawings steeds een geheel vorm, waarvan die verskillende onderdele mekaar steeds in ' $n$ mindere of ' $n$ meerdere mate beînvloed. Dit lei hom tot die vraag: "If there are connections everywhere, why do we persist in turning dynamic, interconnected phenomena into static, disconnected things?"

Wolf (1982:5) suggereer dat die antwoord op dié vraag gesoek moet word in die wyse waarop ons ons eie Westerse geskiedenis geleer het:

We have been taught, inside the classroom and outside of it, that there exists an entity called the West, and that one can think of this West as a society and civilization independent of and in opposition to other societies and civilizations. Many of us even grew up believing that this West has a genealogy, according to which ancient Greece begat Rome, Rome begat Christian Europe, Christian Europe begat the Renaissance, the Renaissance the Enlightenment, the Enlightenment political democracy and the industrial revolution.

Hierdie historiese ontwikkelingskema is misleidend in twee opsigte, aldus Wolf. Eerstens maak dit van die geskiedenis 'n morele suksesstorie, waar die 'goeie ouens' steeds wen en, soos in 'n wedloop, die fakkel van vryheid en beskawing aan die volgende 'wenners' deurgee. Die verloorders is natuurlik steeds die 'bad guys'. Tweedens: "if history is but a tale of unfolding moral purpose, then each link in the genealogy, each runner in the race, is only a precursor of the final apotheosis and not a manifold of social and cultural processes at work in their own time and place." Dit sou-binne die raamwrk van 'n dergelike opvatting-dus byvoorbeeld sinloos wees om die konflikte in die Hellenistiese state én die onderlinge spanninge en oorloë tussen dié state te bestudeer.

In terme van die klassieke en Bisantynse Oudheid kan Wolf se bewering onder meer getoets word binne die kader van die verhouding tussen Oikoumene, Periphereia en die verder afgeleë, meer onbekende 'barbaarse wêreld' in Afrika.

\section{Definisies en persepsies van periphereia in die Oudheid}

Afrika het-volgens die tradisionele wêreldvisie-tot al drie gebiede behoort. Die Noorde (Karthago en die Puniese, daama Latynse Afrika enersyds, en Egipte met Libië andersyds) was deel van die Oikoumene. Die Berbers wat in en uit die Romeinse gebiede beweeg of migreer het, en die stamme van die huidige Soedan (Nubië) en Ethiopië was periferies. Verder suidwaarts het die 'verskroeide wêreld' gelê. 
Dit is die beeld wat die antieke geograwe soos Strabo en Ptolemaios ons gee, wat gevind word in verwysings soos dié van Sallustius na die kroniek van Hiempsal, en wat geillustreer word deur Eratosthenes se definisie van Oikoumene as die bewoonde aarde, 'n gebied wat tussen Thule en Meroë in Nubië geleë was (Cary 1972:344; Sellassie 1972:46-51; Hendrickx 1993:122-123, 366-370).

Afrika, soos dit deur die antieke mens beskou is, het egter geen eenheid gevorm nie, dog bestaan uit twee dele: die regio van die mare nostrum, wat kultureel en ekonomies aangesluit het by die Suid-Europese Middelandse See-gebied en dié van die mare Erythraeum, wat Noordoos Afrika én Jemen (= die antieke Arabia Felix) omvat het. ${ }^{1}$

$\mathrm{Na}$ gelang die definisie van oikoumene en periphereia verander het, het egter ook die grenslyne tussen die twee gebiede verander. Die 'klassieke' (heidense) Oudheid het die Afrika-grense blykbaar bepaal in die lig van geografies-militêre faktore en ekonomiese oorwegings. Die beperkte aantal verkenningstogte deur die Sahara het tot die besluit gelei dat verdere ekspansie suidwaarts nie prakties was nie. Vir die Hellenistiese en Romeinse regerings was dit ekonomies-finansieel ook meer lonend om kommoditeite, soos silwer, goud, ivoor en olifante, te bekom via die kus van Ethiopië en Somalië, eerder as om via Nubië na die sentrale gedeeltes van Afrika deur te dring (Sellassie 1972:53; Tarn \& Griffith 1959:246-248). Noord-Nubië was vir die Grieke, Romeine en Bisantyne slegs van belang as ontginningsgebied van goud. Agatharchides getuig hoe slawe en krygsgevangenes 'n onmenslike taak moes uitvoer in haglike omstandighede (Tarn \& Griffith 1959:254; Cary 1972:246). Handelsuitbreiding was ook Ptolemaios II se dryfveer van sy ekspansie-politiek in die Rooi-See gebied (Cary 1972:80-81) en die Ptolemaioi het veral vanuit Adoulis hul olifantejagte georganiseer (Sellassie 1972:53). Augustus se belangstelling in Jemen, Aden, Hadramaut en Nubië was gerig op beskerming van die handelsroete na Indië en die beveiliging van die Suid-grens van Egipte (Salmon 1957:105-106). Daarom ook het Nero se ekspedisie na Nubië sonder verdere gevolge gebly (Sellassie 1972:56-57). Weer eens ter wille van ekonomies-militêre redes het Diocletianus besluit om die suidelike grens tussen Egipte en Nubië noordwaarts te verskuif tot by die eerste katarak (Papadopoullos 1966:8). Na Justianus se tyd ten slotte was die Bisantynse heerskappy nog slegs nominaal erken in die Soedanese Noorde (Papadopoullos 1966:7).

Die verchristeliking van die Romeinse Ryk het 'n nuwe dimensie gegee aan die verhouding tussen oikoumene en periphereia. Ideologies was die Bisantynse basileus daartoe verbind om, as kosmokrator, die plaasvervanger van God (pantokrator) op aarde, die Christendom uit te dra. Gevolglik was dit die basileus se plig om die wêreld te omskep in God se koninkryk op aarde, waarin die pax byzantina moes heers (Ahrweiler 1977:23-29, 44). Die Bisantyns-Christelike ideologie het dus wêrelddominasie en die bekering van die heidene as ' $n$ imperiale plig daargestel,

1 Die term mare Erythraeum het in die Oudheid nie alleen na die Rooi See, maar ook na die Arabiese en Indiese See verwys. 
wat, soos Papathanasiou (1994:131) dit stel, 'n oikoumeniese protokatheria, of selfs 'n monokratoria, tot gevolg moes hê. Ahrweiler (1977:12-28) het in hierdie verband geargumenteer dat die vroeg-Bisantynse ideologiese opvatting gelei het tot 'n 'ekumeniese droom' van ekspansie na die Weste sowel as na die Ooste: dit het gekulmineer in die verowering van Persië deur keiser Herakleios, maar dié keiser én sy ideologiese drome het katastrofaal in duie gestort as gevolg van die Islamitiese stortvloed (Hussey 1961:23-27).

Die grense van die oikoumene word ook in die Suide verskuif as gevolg van die Christendom se verskyning in dié landstreke. Die oorlog wat in die sesde eeu Justinianus verbind het met die Axumitiese vors Kaleb (alias Elesboas) tot 'n gesamentlike veldtog om die Judese Ryk van Dhu-Nuwas in Jemen te vernietig en te vervang met 'n Christelike 'Homeritiese' (= Jemenitiese) staat, is 'n gevolg van die nuwe ideologie (Ryckmans 1956:18-21; Sellassie-1972:128-135; Letsios 1988:240259; Papathanasiou 1994:23-45, 112).

\section{Die bronne en hul waarde}

Oor watter bronne beskik ons om die Rooi-See gebied grondig te bestudeer?

Die gepubliseerde Griekstalige Nubiese, Ethiopiese en 'Homeritiese' tekste, wat verwys na die historiese Axumitiese basileis en die Nubiese basiliskoi is redelik beperk in aantal: dit omvat ' $n$ aantal oorkondes (naamlik die Nubies-Axumitiese koningsepigrafie, -briewe en -papiri, insluitend die bekende Gebelen-dokumente), enkele kronieke en die sogenaamde wetboek van die Homeriete (of sogenaamde wette van Gregentius) ${ }^{2}$. Hierdie tekste kan aangevul word met 'n aantal Griekse en Koptiese papiri, testimonia van Bisantynse kroniekskrywers, inskripsies in Ge'ez en Sabaies uit Ethiopië en Jemen en enkele Siriese geskrifte ${ }^{3}$.

Die Kebra Negast is die belangrikste inheemse geskrif: 4 ofskoon die finale versie van dié groot werk slegs gedurende die 13de eeu gefinaliseer is loop die tradisie wat daarin opgeneem is terug na die eerste eeue na Christus (Letsios 1988:88). Die werk is egter epies van aard, en die gegewens moet baie krities benader word, alhoewel etlike geleerdes (o.m. Ullendorff 1973:139; Papathanasiou $1994: 49,132-134)$ meen dat die werk, indien nie die feite nie, dan tog wel die ideologie en persepsies van die Axumitiese keiserryk getrou weerspieël het.

\section{Akkulturasie en sinkretisme in die periphereia}

Egipte is erken deur die Afrika-bronne as 'n deel van die Hellenistiese en Romeins-Bisantynse wêreld. Die sesde-eeuse Gebeleïn-tekste, wat van Blemiër

\footnotetext{
2 Vir uitgawes en besprekings van hierdie bronne, sien veral Krall 1900:4-5; Hägg 1984:101112; Papathanasiou 1994:45-57.

3 Vir 'n volledige oorsig, sien Sellassie 1972:16-17; Letsios 1988:30-41; Papathanasiou 1994:46-51.

4 In hierdie artikel word verwys na die Engelse uitgawe van Budge (1932). Vir 'n meer resente bespreking, sien Shahib 1976.
} 
(Beja) amptenare en vorste uit die Nubies Egiptiese grensgebied afkomstig is, werp lig op hierdie opvatting. Die Egiptenare word gewoonweg 'Romeine' genoem, d.w.s burgers van die Oos-Romeinse-Bisantynse Ryk. ${ }^{5}$

- ETR XAPAXHN BACIAEICKOC TRN BAEMTRN ... (Krall 1900:4)

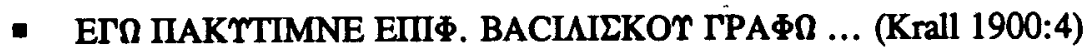

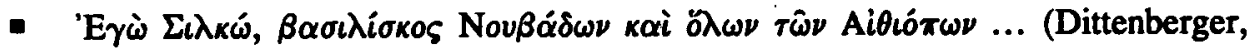
OGI 1.201; Papadopoullos 1966:117; Hendrickx 1984:75).

Hierteenoor laat die titels van die Axumitiese vorste, selfs van die oudstes onder hulle waarvan die naam en chronologie onbekend is, geen twyfel oor húl siening nie. Húlle is basileis:

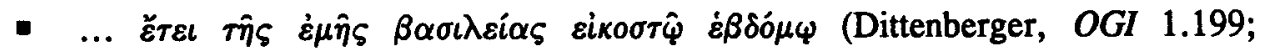
Hendrickx 1984:36)

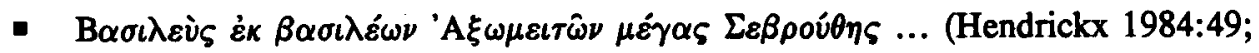
Littmann 1913:4.3)

- ... $\sigma \grave{\nu} \nu \tau \hat{\varphi} \beta \alpha \sigma \iota \lambda \varepsilon \hat{\imath} \ldots$... (Sayce 1909:189; Selassie 1972:91; Hendrickx 1984:51)

- 'A Hendrickx 1984:53).

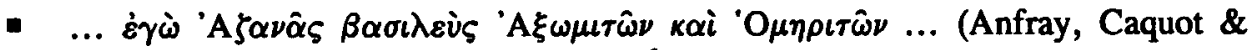
Nautin 1970:265; Hendrickx 1984:56). ${ }^{6}$

Reeds Krall (1900:6) het opgemerk dat die Nubiese basiliskoi die senioriteit of soewereiniteit van die Bisantynse en/of Axumitiese vors hiermee erken het (vgl. ook Kobishchanov 1979:193; Letsios 1988:209; Papathanasiou 1994:109-110). Die verskil in wêreldvisie tussen die twee groepe is duidelik. Axum eis gelykheid op met Konstantinopel, Nubië aanvaar ondergeskiktheid ten opsigte van een of albei die

$5 \quad$ Byvoorbeeld in 'n dokument van die Blemiër, Charachen, waar die 'Romeine' (= Egiptenare) blykbaar belasting moet betaal t.o.v. die huur of gebruik van die Nyl-eiland Tanare (Krall 1900:4).

6 Die Ethiopiese vorste het reeds voor die veldtog teen Dhu Nuwas (sesde eeu) die titel van 'koning van die Ethiopiërs en Homeriete' gedra. Hulle het waarskynlik reeds in die vierde eeu (Ezana se tyd) die (teoretiese) soewereiniteit oor Suid Arabië uitgeoefen (Sellassie 1972:92). Daar moet ook opgemerk word dat sowel Ezana as Sebrouthis die titels van 'koning van die konings' (= keiser) gebruik het. Dié titel het later die tradisionele titel van die Ethiopiese negus geword. 
keiserryke. In die laaste geval beskou Nubië sigself nie as periferies nie, dog as 'n onafhanklike buffergebied tussen die twee ryke.

Dieselfde is waar vir die Christelike 'Homeritiese' Ryk. Die sogenaamde wetboek van die Homeriete, wat in feite 'n kroniek is oor die ontstaan van dié Ryk met 'n opsomming van die nuwe Christelike wette en 'n biografie van biskop Gregentius (Papastathis 1991:115-126; Papathanasiou 1994:52-68), verwys egter na die 'Homeritiese' vors as basileus. Maar die historiese konteks verklaar dit: die Judese koning van Jemen, Dhu Nuwas, is verslaan deur 'n Bisantyns-Axumitiese koalisie, en die basileus Kaleb (Elesboas) van Axum word gevolglik ook de facto en de jure basileus van die Homeriete. Kaleb keer egter terug na Ethiopië en in Jemen word 'n lokale leier, Esimiphaios (Abraha)-volgens Bisantynse tradisie-tot 'medekeiser' gekroon. ${ }^{7}$ Esimiphaios (Abraha) se opvolgers behou die keiserstitel en volg 'n vriendskaplike, dog neutrale politiek teenoor Axum en Bisantium. Die sogenaamde Wetboek van die Homeriete, aldus Papathanasiou (1994:134), weerspieël duidelik hierdie bewuste poging tot onafhanklikheid.

Die kroning van Esimiphaios (Abraha) as medekeiser verwys na akkulturasie: Bisantynse keiserritusse word deur 'n biskop, wat deur die patriarg van Alexandrië gestuur is, in Jemen op bevel van die Ethiopiese vors toegepas, en die tradisie word behou tot by die inval van die Moslems.

Die Gebeleïn-tekste dui aan hoe Romeins Bisantynse invloede vanuit die Koptiese Egipte deursypel in Nubië en hul stempel afdruk op lokale instellinge en die regswese (Chrysos 1978:44-45). Daar word gepraat van die KOTPATMPIA (= beheer van die eiland Tanare: Krall 1900:4). Kontrakte word afgesluit deur 'n

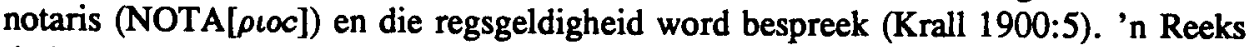
titels weerspieël ook die simbiose van Konstantinopel en Afrika: die phularchos (hiërargies onder die basiliskos) is waarskynlik die stamhoof (Krall 1900:4; Hägg 1984:101, 108); daar is sprake van 'n turannos in die Triantakontaschoeinos-gebied (Letsios 1988:105) en 'n hupoturannos op die eiland Tanare (Krall 190:4). Die basiliskoi se hof, parallel aan die Bisantynse, kan spog met domestikoi en het sy eie grammateis (Krall 1900:4-5; Hendrickx 1984:75).

In hoeverre dié akkulturasie gelei het tot 'n werklike assimilasie van die sogenaamde periphereia gebied ten opsigte van Bisantium is moeilik om te bepaal. In elk geval het die akkulturasie ook 'n kulturele sinkretistiese aspek: hiervan getuig onder meer die afbeelding van koning Silko te Philae: dié basiliskos dra 'n Romeinse paludamentum en tunica, Egiptiese faraoniese attribute en die Nubiese Ballana-kroon (Castiglione 1970:98), simbole van die nastrewing van kultuureenheid en gelykstelling van waardes.

7 Oor die verwarring tussen Esimiphaios (wat ook die doopnaam Abraha gedra het) en sy opvolger, die usurpator Abraha, sien Papathanasiou 1994:63. Oor die betekenis van die ritus van die Bisantynse keiserskroning, sien Bréhier 1970:14-18. 


\section{Die Axumitiese wêreldvisie}

Die Kebra Negast se verwysings na Rome/Konstantinopel is drievoudig. Dit beskryf (a) die legendariese verbintenisse tussen Rome/Konstantinopel en Israel, (b) die historiese verchristeliking van Bisantium onder Konstantyn asook die vroeë ketterye, en (c) die historiese 6de-eeuse oorloë in Jemen tussen Judese Homeriete en die gesamentlike magte van Justinianus en Kaleb.

Ofskoon die legendariese gegewens in die Kebra Negast nie aanvaar kan word nie, gee dit tog 'n duidelike beeld van die Ethiopiese eiebeeld en wêreldkonsepsie. Die Kebra Negast verhaal inderdaad hoe die Ethiopiërs-saam met die Israelietedie uitverkore volk van God is en daarom toegelaat word om die Ark van die Verbond uit Jerusalem te steel en oor te bring na Axum (Kebra Negast, hfste. 48$55,61,84-94)$.

Die verhaal bepaal ook herhaaldelik die plek van Ethiopië ten opsigte van die Romeinse keiserryk (=Bisantium). Die rol van die Grieke as sodanig word reeds geskets in hoofstuk 67, waar die Engel van die Here aan Salomo die lot van sy drie seuns voorspel:

The one who carried off thy glory [= die Ark] into an alien land, and made the habitation of God to be in Ethiopia; the one who is lame of foot, who shall sit upon thy throne for the people of Israel, the son of the kin of thy kin from Tarbâna, of the house of Judah; and the one who is the son of a Greek woman, a handmaiden, who in the last days shall destroy Rehoboam and all thy kin of Israel; and this land shall be his because he believeth in Him that shall come, the Saviour. (Budge 1932:108)

Dit is ' $n$ handige inleiding tot die bespreking van die keiserryk van Rome (Bisantium) (hfst. 72), waarvan die genealogie aangedui word: Rome was toegeken aan Japhet, seun van Noag; daarna het Dareios die grootste stede van dié ryk gebou (Antiochië, Tyros, Parthië en Rome); vervolgens het Konstantyn Konstantinopel gebou en sy eie naam aan die stad gegee; ten slotte het Konstantyn die Christendom ingestel. Handig word Dareios ook met die voorvaders van Salomo verbind, en weer eens word Salomo dié keer per brief ingelig oor die glorie van die drie groot ryke (Israel, Ethiopië, Rome = Bisantium). Gevolglik het Salomo sy Griekse seun, Adramis, aan die dogter van keiser Balthasar van Rome (Bisantium) ter huwelik gegee. Adramis het Balthasar opgevolg.

In dieselfde konteks van legende en half-mitiese genealogie, word ook die konings van Mediē, Babilon, Persië, Moab, Amalek, van die Filistyne en die Ismaëliete asook die Farao's vermeld, maar dan as mindere konings rondom die drie 'groot' ryke.

Dit is duidelik dat die Kebra Negast se 13de-eeuse samesteller, Isaak, die verskillende tradisies wat hy geken en versamel het, sonder enige chronologiese insig of perspektief deurmekaar en langs mekaar geplaas het in sy finale kompilasie. Isaak, waarvan ons geen besonderhede ken nie, het waarskynlik gebruik gemaak van 'n ouer weergawe in Arabies, maar hy het-volgens Budge (1932:xxxvii-xli)-die Kebra Negast as't ware herskryf, aangevul en herinterpreteer. 
In hoofstuk 93 word weer na 'n historiese konteks oorgegaan:

For the kings of Ethiopia and the kings of Rome were brethren and held the Christian Faith. Now first of all they believed in an orthodox manner in the preaching of the Apostles up to [the time of] Constantine, and Eleni the Queen, and they brought forth the wood of the Cross, and they continued [to believe for] one hundred and thirty years. And afterwards, Satan, who hath been the enemy of man from of old, rose up, and seduced the people of the country of Rome, and they corrupted the Faith of Christ, and they introduced heresy into the Church of God by the mouth of Nestorius. (Budge 1932:164)

Ook Arius word as ketter genoem. Na die verval van die geloof in Rome word ook verder in hoofstuk 113 (Budge 1932:221-223) verwys. ${ }^{8}$

Papathanasiou (1994:130-134) het onlangs gepraat van sesde-eeuse 'Yalta Ooreenkomste', wat soos na die Tweede Wêreldoorlog die wêreld sou opgedeel het in invloedsfere tussen die belangrikste regerings. Papathanasiou het sy stelling gegrond op die Kebra Negast se getuienis in hoofstuk 20:

From the middle of Jerusalem and from the north thereof to the south-east is the portion of the Emperor of Rôm; and from the middle of Jerusalem from the north thereof to the south and to Western India is the portion of the Emperor of Ethiopia (Budge 1932:16).

Hoofstuk 117 (Budge 1932:225-226) verwys na dieselfde episode, wat volgens die verhaal die gevolg was van 'n ontmoeting tussen keiser Justinus en Kaleb te Jerusalem. Die ontmoeting word egter deur geen ander bron bevestig nie en moet as fiktief beskou word.

Die vraag moet daarom gestel word in hoeverre die Kebra Negast se verhaal werklik sesde-eeuse toestande weerspieël, of in feite 'n later projeksie van middeleeuse konsepsies in die verlede is. Die feit dat die hedendaagse geleerdes blykbaar die eerste stelling ondersteun, is nie 'n bewys per se nie. Tereg het die Ethiopiese akademikus Sellassie (1972), dan ook in sy werk dié vroeẽ periode met die nodige omsigtigheid behandel en hom streng aan die eietydse bronne gehou.

\section{Besluit}

Die voorbeeld van Afrika illustreer dat Wolf se stellings as onvolledig en eensydig bestempel moet word vir sover dit die Oudheid betref. Meer bepaald kan tot die volgende gevolgtrekkings gekom word:

- Die opstel van genealogieë is nie eie aan die Weste sensu stricto nie, en ook ons eie tydperk nie. Die voorbeeld van die genealogie uit die Kebra Negast illustreer dit.

8 Die Ethiopiese (en Koptiese) Kerk was monofisities. Dit is insiggewend om op te merk dat die Axumiete die Ortodokse Bisantyne as 'ketters' beskou. 
- Die Weste se genealogie, soos deur Wolf beskryf word, is dalk nie so eie aan die Weste as wat die outeur dit voorstel nie. Reeds vroeg het die Bisantynse ideologie afgewyk van die Wes Romeinse. Tog het albei groepe-én Axum!blykbaar 'n gelykaardige genealogie begin ontwikkel.

- Die gelykstelling van 'eie beskawing' met 'goed' as teëgesteld aan 'anders = verkeerd' is ook nie eie aan die Weste nie. 'Die Axumiete se siening van die Bisantynse Ortodokse as 'afvallig' en hulself (d.w.s. die monofisiete) as aanhangers van die 'ware' geloof, bewys hierdie punt.

- Ten slotte kan-in antropologiese terme-die antieke periphereia, in casu die Christelike Rooi See gebied, gedefinieer word as 'n dinamiese fenomeen van tydelike en ruimtelike relasies, waarvan die eksistensie en ekstensie veral van ekonomiese en godsdienstige faktore afhanklik was.

\section{BIBLIOGRAFIE}

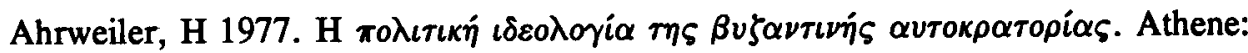
Argo.

Anfray, E, Caquot, A \& Nautin, P 1970. Une nouvelle inscription grecque d'Ezana, roi d' Axoum. Journal des Savants, 260-274.

Bréhier, L 1970. Les institutions de l'empire byzantin. Parys: Albin Michel.

Budge, E A W 1932. The Queen of Sheba and her Only Son Menyelik (I) Being the 'Book of the Glory of Kings' (Kebra Nagast). Oxford: University Press.

Cary, M 1972. A History of the Greek World: 323 to 146 BC. Londen: Methuen \& Co.

Castiglione, L 1970. Diocletianus und die Blemmyes. Zeitschrift für Aegyptische Sprache und Altertumskunde 96, 90-103.

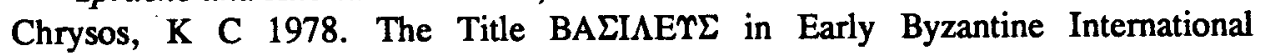
Relations. Dumbarton Oaks Papers 32, 31-75.

Dittenberger, W 1903. Orientis Graeci Inscriptiones Selectae. Leipzig.

Hägg, T 1984. Nubico graeca I-III (Bemerkungen zu Griechischen Texten aus Nubiën). ZPE 54, 101-112.

Hendrickx, B 1984. Official Documents Written in Greek llustrating the Ancient History of Nubia and Ethiopia (3rd Century B.C. 6th Century A.D.). Johannesburg: I.A.H.S. (Monumenta Afro-Hellenica 1.)

Hendrickx, B 1993. Geskiedenis van die Romeins Hellenistiese beskawing (ca 330 30 v.C.). Johannesburg: RAU.

Hussey, J 1961. The Byzantine World. Londen: Hutchinson University Library.

Kobishchanov, Y M 1979. Axum. University Park \& London: Pennsylvania State University Press.

Krall, I 1900. Beiträge zur Geschichte der Blemyer und Nubiër. Denkschriften der Kaiserlichen Akademie der Wissenschaften. Philos.-Hist. Classe. Wien.

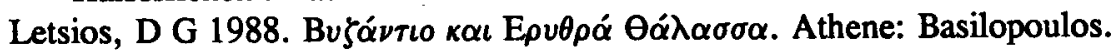


Littmann, E 1913. Sabaische, Griechische und Altabessinische Inschriften. Berlin: Deutsche Aksum-Expedition.

Papadopoullos, T 1966. Africanobyzantina: Byzantine Influences on Negro Sudanese Cultures. Athene: Academy.

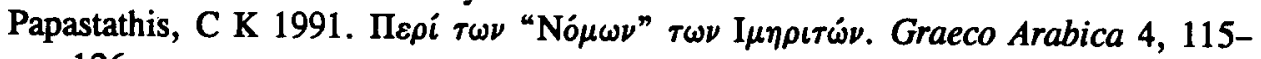
126.

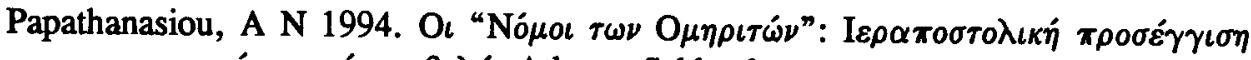
$\kappa \alpha \iota \iota \sigma \tau о \rho \iota \kappa \dot{\eta}-\nu о \mu \iota \kappa \dot{\eta} \sigma \nu \mu \beta 0 \lambda \dot{\eta}$. Athene: Sakkoula.

Ryckmans, J 1956. La persécution des Chrétiens himyarites au sixième siècle. Istanbul: Nederlands Historisch-Archaeologisch Instituut.

Salmon, E T 1957. A History of the Roman World: 30 B.C.-A.D. 138. Londen: Methuen \& Co.

Sayce, A H 1909. A Greek Inscription of a King (?) of Axum Found at Meroë. Proceedings of the Society of Biblical Archaeology 31, 189-203.

Sellassie, S H 1972. Ancient and Medieval Ethiopian History to 1270. Addis Ababa: United Printers.

Shahib, I 1976. The Kebra Nagast in the Light of Recent Research. Le Muséon 89, 133-178.

Tam, W \& Griffith, G T 1959. Hellenistic Civilisation. Londen: Methuen.

Ullendorff, E 1973. The Ethiopians: An Introduction to Country and People. Oxford: University Press.

Wolf, E R 1982. Europe and the People without History. Berkeley: University of California Press. 